139

Received: July 10, 2012

Accepted: November 25, 2012
Macedonian Journal of Animal Science, Vol. 3, No. 1, pp. 3-7 (2013)

In print ISSN $1857-6907$

On line ISSN $1857-7709$

UDC: $636-2.082 .28(560)$

Original scientific paper

\title{
COMPARISON OF SOME REPRODUCTIVE TRAITS OF ANATOLIAN AND F 1 CROSSBRED (ANATOLIAN×ITALIAN) BUFFALOS UNDER VILLAGE CONDITIONS IN TURKEY
}

\author{
Özel Şekerden \\ Department of Animal Science, Faculty of Agriculture, Mustafa Kemal University, Antakya, Turkey \\ sekerden@mku.edu.tr
}

\begin{abstract}
This study compares reproductive traits of Anatolian and Anatolian $\times$ Italian $\mathrm{F}_{1}$ crossbred buffalos in Ilıkpınar Village of Kırıkhan District of Hatay Province, Turkey. Previous studies of the same genotype compared growth characteristics, milk yield and somatic cell numbers in milk and this present study has dealt with some reproductive traits. The study material involves various breeding control records of Anatolian and Anatolian $\times$ Italian crossbred female buffalos. The buffalos in various lactation orders were from two buffalo herds of Ilıkpinar Village of Kirıkhan District, Hatay Province. The records cover periods from 2001 to 2011 and 2003 to 2011, respectively, for Anatolian and crossbred buffalos. The numbers of Anatolian and $\mathrm{F}_{1}$ crossbred buffalos in terms of traits and genotype were respectively 12 and 10 for the first calving age; 87 and 21 for the calving interval; and 20 and 5 for two gestation period. The effects of the genotype and the calving year on the examined features were determined by the GLM variance analysis and mean values were calculated by using the SPSS Programme. It was concluded that there was no significant difference between Anatolian and Anatolian $\times$ Italian $\mathrm{F}_{1}$ crossbreeds in terms of the examined reproductive traits.
\end{abstract}

Key words: buffalo; Anatolian; Italian; crossbred; reproductive traits

\section{СПОРЕДБА НА НЕКОИ РЕПРОДУКТИВНИ СВОЈСТВА НА АНАДОЛИСКИТЕ БИВОЛИ СО Ғ 1 МЕЛЕЗИ (АНАДОЛИСКИ×ИТАЛИЈАНСКИ) ВО СЕЛСКИ УСЛОВИ ВО ТУРЦИЈА}

\begin{abstract}
Во студијата се споредуваат репродуктивните својства на анадолискиот бивол и мелезите помеѓу анадолискиот $\times$ италијанскиот бивол од $\mathrm{F}_{1}$ генерација во селото Ilıkpınar, област Kırıkhan во провинцијата Хатај во Турција. Во претходните студии врз истиот генотип се споредувале карактеристиките на растежот, млекопродукцијата и бројот на соматските клетки во млекото, додека оваа студија се занимава со одредени репродуктивни својства. Опитниот материјал вклучува различни одгледувачки контроли кај женки од анадолискиот и мелези помеѓу анадолискиот×италијанскиот бивол. Биволите од различна лактација беа од две стада, од селото Ilıkpınar, област Kirıkhan во провинцијата Хатај. Податоците ги опфаќаат периодите од 2001 до 2011 и од 2003 до 2011, соодветно за анадолискиот бивол и биволите мелези. Бројот на анадолискиот бивол и на мелезите од $\mathrm{F}_{1}$ генерација во однос на својството генотип беше 12 и 10, соодветно при првото телење, 87 и 21 во меѓутелидбениот период и 20 и 5 во гестацискиот период. Ефектите на генотипот и годината на телење врз испитаните особини, утврдени со варијабилната анализа GLM и средните вредности се пресметани со користење на програмата SPSS. Констатирано е дека не постои значајна разлика меѓу анадолискиот бивол и мелезите помеѓу анадолискиот×италијанскиот бивол во однос на испитаните репродуктивни особини.
\end{abstract}

Клучни зборови: биволи; анадолиски; италијански; мелез; репродуктивни својства

\section{INTRODUCTION}

The main factors affecting profits in milk herds are the productive and reproductive yields. However, there is an inverse relationship between milk yield and reproductive traits [1]).

Reproductive traits of buffalos are affected by climatic conditions, genotype, nutrition and herd management [2]. Genotype is the main factor affecting reproductive traits, since factors such as sexual maturity, the first mating age, calving interval, service period, whether the oestrus period passed clearly or silently and reactions to feed and feeding systems vary between breeds and individuals in the same breed.

Buffalos have low heredity of reproductive traits, demonstrating that such traits are affected 
by many environmental factors. Therefore, reproducetive traits in buffalos show significant variance $[3,4,5,6]$.

Various climatic factors and their interactions, climatic alterations are effective in reproduction and milk yield performance [7, 8]. Although buffalos can adapt perfectly to hot and humid climates, they show great stress indications under hot weather when directly exposed to the sun. Heat stress reduces the oestrus period and its clarity negatively affects feed and energy intake [9].

Aziz et al. [10] determined the significance $(\mathrm{P}<0.01)$ of the effect of the calving year on the calving interval in Egyptian buffalo. However, Prakash et al. [11] about Murrah buffalos and Afifi et al. [3] about Egyptian buffalos reported that this effect was not significant.

Feeding and herd management are the most important environmental factors affecting the reproductive yield of buffalos. In case of insufficient energy intake, sexual maturity is delayed and conception rate decreases; in case of protein deficiency in rations, appetite reduces, and therefore sexual maturity is delayed and the days open increases [12]. Improving feeding level reduces both the service period and the calving interval in any lactation order in all animals [13].

Previous studies of the reproductive performance of buffalos reported significantly different results due to genetic diversity and different environmental conditions [14].

The first calving age was reported as 1075 days in Anatolian buffalos [15], and as 50 and 40.3 months in Murrah and Nili-Rarvi buffalos, respectively [16]. The first calving age was reported in Egyptian buffalos as 38 months by Afifi et al. [3]; in Australian buffalos 39, in Malaysia buffalos 4248 months by McCool [17]; in Italian buffalos 36 months by Larsson [18]. In a study, Fooda et al. [19] reported the first calving age of Egyptian buffalos as 29 and 31 months in $1^{\text {st }}$ and $2^{\text {nd }}$ farms; of Egypt $\times$ Italian crossbreeds as 27 months and 31 months in $1^{\text {st }}$ and $2^{\text {nd }}$ farms.

The calving interval was $470.4 \pm 19.0,423.0 \pm$ 21.5 and $564.6 \pm 98.5$ days in $1^{\text {st }}, 2^{\text {nd }}$ and $3^{\text {rd }}$ calving interval orders respectively in Anatolian buffalos [20]; 437.2 days in Romanian buffalos [21]; 512.7 \pm 9.4 and $538.3 \pm 11.4$ days in Murrah and Surti buffalos respectively in India [22]; $455 \pm 5$ and $481 \pm 30$ days in Murrah and Nili-Ravi buffalo, respectively, in another study [16]; 500 days in Egyptian buffalos by Afifi et al. [3]; 15 months and 13-36 months in Australian and Malaysian buffalos, re- spectively by McCool [17]; 400-500 days in Italian buffalos by Larsson [18]; 395 days and 418 days in $1^{\text {st }}$ and $2^{\text {nd }}$ farms of Egyptian buffalos, and 429 and 433 days in $1^{\text {st }}$ and $2^{\text {nd }}$ farms of $F_{1}$ by Fooda et al. [19].

The gestation period was found $320 \pm 1.20$ days in Anatolian buffalos by Uslu [20]; 308 days in Bangladesh buffalos by Faruque [23]; 307-316 days in Egyptian buffalos by Metry [25]; 308-314 days in river buffalos by McCool [17]; 317 days and 315 days in $1^{\text {st }}$ and $2^{\text {nd }}$ farms of Egyptian buffalos and 314 days and 313 days in $1^{\text {st }}$ and $2^{\text {nd }}$ farms of Egyptian $\times$ Italian crossbreds $F_{1 s}$ by Fooda et al. [19].

In a comparison of reproductive traits of Egyptian buffalos and Egyptian $\times$ Italian crossbred $\mathrm{F}_{1}$ buffalos in 2 different farms, Fooda et al. [19] reported that all reproductive traits (calving interval, service period, the days open), except the first calving age in crossbred buffalos, are greater than the ones of Egyptian buffalos and the reproductive traits of Egyptian buffalo are better than Italian $\times$ Egyptian $F_{1}$ crossbred buffalos.

Previous studies of the same genotype compared growth characteristics [25], and milk yield and somatic cell numbers in milk [26]; and this present study examined the reproductive traits of Anatolian and Anatolian $\times$ Italian $F_{1}$ crossbred buffalos in village conditions in Turkey.

\section{MATERIALS AND METHODS}

The study was conducted in 2 farms representing buffalo herds of Kırıkhan Ilıkpınar Village of Hatay Province. The study material consists of various breeding records of Anatolian and Anatolian $\times$ Italian crossbred buffalos in various lactation orders*. The records cover the periods from 2001 to 2011 for Anatolian and 2003 to 2011 for $F_{1}$ buffalos**.

Ilıkpınar Village has an appearance like a big buffalos farm with approximately 150 breedable buffalos. Almost all feeding is based on the gra-

\footnotetext{
*The material of the study (Anatolian and $\mathrm{F}_{1}$ crossbred) was formed by buffalos conceived and calved inseminated artificially after being synchronized the oestrus, and their progenies. $F_{1}$ were obtained in the Turkish-Italian Cooperative Project on Genetic Improvement (Genetic Improvement of Anatolian Buffalos by Crossing with Italian Buffalos) that, was supported by FAO.

${ }^{* *}$ The first inseminations were made in April, 2002 within the scope of the Project with Turkish-Italian cooperation. Therefore, the records of $F_{1}$ s have been kept since 2003.
} 
zing land of the village. In one of the study units, a limited amount of silage is produced and additional feed is given after the return from pasture. In the other farm, the feeding level is lower. Births generally occur during March and April.

Breeding records of Anatolian buffalos have been kept by the author since 1996. Inseminations were started in April, 2002, within the scope of an Anatolian $\times$ Italian Crossbreeding Project, and the first crossbred calves were born in 2003. Since the animals studied were from the village herd, the animals were artificially inseminated after their oestrus was synchronized. Therefore, gestation periods could be calculated only in Anatolian and $\mathrm{F}_{1}$ buffalos within the Project. Table 1 shows the data evaluated according to the examined features. The evaluation was made in combination of the data of some years there were a few data, with others for each trait (Table 1).

Table 1

Baseline data for the evaluation of the features examined in this study $(x)$

\begin{tabular}{llllllc}
\hline \hline \multirow{2}{*}{$\begin{array}{l}\text { Environmental } \\
\text { factor }\end{array}$} & \multicolumn{2}{c}{ First calving age } & \multicolumn{2}{c}{ Calving interval } & \multicolumn{2}{c}{ Gestation period } \\
& Subgroup & $\mathrm{N}$ & Subgroup & $\mathrm{N}$ & Subgroup & $\mathrm{N}$ \\
\hline Genotype & Anatolian & 12 & Anatolian & 87 & Anatolian & 20 \\
& ${\text { Crossbred } \mathrm{F}_{1}}_{\text {Calving Year }}$ & 10 & Crossbred $\mathrm{F}_{1}$ & 21 & Crossbred F $_{1}$ & 5 \\
& 2001 and 2002 & 7 & 2001 and 2002 & 19 & 2003,2004 & 11 \\
& $2003,2004,2006$ & 6 & 2003,2004 & 21 & $2005,2006,2007$ & 7 \\
& $2007,2008,2009$ & 9 & 2005,2006 & 15 & $2008,2009,2011$ & 7 \\
& & 2007,2008 & 20 & & \\
\hline Total & & $2009,2010,2011$ & 33 & & 25 \\
\hline \hline
\end{tabular}

The effects of the genotype and the calving year on the examined features were examined through GLM (General Linear Model) analysis of variance (ANOVA). To that end, a simple linear model (Equation 1) including variance sources considered for each feature was used;

$$
Y_{i j m}=\mu+G_{i}+C_{\text {yearj }}+\left(G \cdot C_{\text {year }}\right)_{i j}+e_{i j m} .
$$

where; $Y_{i j m}$ : Examined feature (for example gestation period), $\mu$ : General average, $G$ : Genotype effect $\left(i\right.$ : Anatolian, $\left.\mathrm{F}_{1}\right)$, Cyear: The effect of the calving year $(j: 1,2,3,4,5),\left(G \cdot C_{\text {year }}\right)_{i j}$ : The inter- action between the genotype and the calving year, $e_{i j m}$ : Error term.

Averages were calculated for the examined features for each genotype. SPSS was used in all statistical analyses.

\section{RESULTS}

Table 2 shows ANOVA results of various features and Table 3 shows averages of investigated characteristics.

Table 2

Analysis of variance of calving interval, first calving age and gestation period

\begin{tabular}{|c|c|c|c|c|c|c|c|c|c|}
\hline \multirow[t]{2}{*}{ Variance Source } & \multicolumn{3}{|c|}{ Calving interval } & \multicolumn{3}{|c|}{ First calving age } & \multicolumn{3}{|c|}{ Gestation period } \\
\hline & f.d. & $\mathrm{F}$ & Significance & f.d. & $\mathrm{F}$ & Significance & f.d. & $\mathrm{F}$ & Significance \\
\hline Genotype & 1 & 0.368 & & 1 & 0.696 & 0.416 & 1 & 0.150 & 0.703 \\
\hline Calving year & 4 & $2.659 *$ & 0.037 & 2 & 1.004 & 0.387 & 2 & $2.815^{*}$ & 0.084 \\
\hline Genotype*Calving year & 1 & 0.774 & 0.381 & 1 & 0.535 & 0.474 & 1 & 0.218 & 0.645 \\
\hline Error & 101 & & & 17 & & & 20 & & \\
\hline Total f.d. & 108 & & & 22 & & & 25 & & \\
\hline The average of error square & \multicolumn{3}{|c|}{21164.949} & \multicolumn{3}{|c|}{18743.881} & \multicolumn{3}{|c|}{77.143} \\
\hline $\mathrm{R}^{2}$ & \multicolumn{3}{|c|}{0.116} & \multicolumn{3}{|c|}{0.224} & \multicolumn{3}{|c|}{0.221} \\
\hline
\end{tabular}

$* \mathrm{P}<0.05$, Coefficient determination of model 
Table 3

Average calving interval, first calving age and gestation period (days) (x).

\begin{tabular}{lccccccc}
\hline Environmental factor & Subgroup & \multicolumn{2}{c}{ Calving interval } & \multicolumn{2}{c}{ First calving age } & \multicolumn{2}{c}{ Gestation period } \\
\cline { 3 - 8 } & & $\mathrm{N}$ & $\mathrm{X} \pm \mathrm{SX}$ & $\mathrm{N}$ & $\mathrm{X} \pm \mathrm{SX}$ & $\mathrm{N}$ & $\mathrm{X} \pm \mathrm{SX}$ \\
\hline Genotype & Anatolian & 87 & $599.2 \pm 15.27$ & 13 & $1210.4 \pm 35.38$ & 20 & $313.3 \pm 2.06$ \\
\cline { 2 - 8 } & $\mathrm{F}_{1}$ & 21 & $545.2 \pm 38.5$ & 10 & $1126.4 \pm 44.37$ & 5 & $314.0 \pm 4.21$ \\
\hline
\end{tabular}

\section{DISCUSSION}

The effect of the genotype was non-significant for 3 of the examined features. The calving year is related to significant variance in calving interval and gestation period (Table 2). The significant effect of the calving year may be due to climatic changes that occurred during the 10-year period of the study. Since the feeding depends on grazing areas in the village, the change in the feeding system is an anticipated outcome. On the other hand, feeding is one of the most influential environmental factors on reproductive traits $[2,12$, 13]. While some studies in the literature reported that the calving year significantly affects the calving interval [10], others found that this effect was insignificant $[3,11]$.

While the averages of the calving interval, the first calving age and the gestation period are shorter in $F_{1} s$ (Table 3 ), the differences between Anatolian and $F_{1} s$ for these features are not significant (Table 2). It may be stated that average gestation period is the same in both genotypes (Table 3).

The averages of the calving interval, the first calving age and the gestation period obtained from this study can be compared with those in literature as follows:

The average calving interval determined for the Anatolian breed is longer than the reported one in both other studies in the literature [20], and those reported for various breeds in different countries. The average calving interval determined in this present study for $F_{1}$ crossbreeds is close to the result of one study in the literature (Neog et al. [22] in Murrah and Surti breeds), a little shorter than the value of $3^{\text {rd }}$ calving order given for the Anatolian breed in the literature [20], and longer than other results.

The first calving age average calculated for the Anatolian breed is older than the results of some studies $[3,19,20]$, shorter than the results of some studies (Anonymous [16] for Murrah breed; McCool [17] for Malaysian buffalos), and similar to the results of some studies (Anonymous [16] for Nili-Ravi buffalos; McCool [17] for Australian buffalos; Metry [24]; Larsson [18]) in literature. The first calving age average calculated for $F_{1}$ genotype is smaller than the results of some studies (Anonymous [16] for Murrah and Nili-Ravi buffalos; Afifi et al. [3]; McCool [17] for Australian and Malaysian buffalos), greater than the result of one study (Fooda et al. [19]), and similar with the results of some studies (Uslu [20]; Metry [24]; Larsson [18]) in literature.

The averages of the gestation period in Anatolian and $F_{1}$ ones are similar in this study. The gestation period determined for Anatolian $\times$ Italian $\mathrm{F}_{1}$ crossbreeds is the same as that determined for Egyptian $\times$ Italian $F_{1}$ crossbreeds by Fooda et al. [19]; the gestation period average determined for the Anatolian breed is slightly shorter than that determined for Egyptian buffalos by Fooda et al. [19]. The gestation period averages determined for Anatolian and Anatolian $\times$ Italian $\mathrm{F}_{1}$ crossbreeds is similar to the results of only one study (close to the top level stated by McCool [17] for river buffalos) in the literature apart from the study by Fooda et al. [19], which is shorter than the result reported by Uslu [20]) for the Anatolian breed and longer than the results of Faruque [23].

It would be expected that the averages found in this present study for reproductive traits would differ from the results of most studies in the literature. This variation is due to the genetic diversity and different environmental conditions, such as feeding and herd management (Borghese et al. [14]; Thevamanoharan et al. [4]; Ramos et al. [5]; Jabalkandi [6]; Perera [2]). This outcome may be explained because the present study was conducted in village conditions, in which feeding was almost entirely dependent on grazing lands, whereas the 
other studies in the literature were conducted in different countries and regions, in different research herds and under different climatic conditions. Thus, the previous results for the Anatolian breed [20] were obtained from a study conducted at the Afyon Buffalo Research Institute.

In conclusion, the present study found no significant difference between Anatolian breed and Anatolian $\times$ Italian $F_{1}$ crossbreeds in terms of the examined reproductive traits.

\section{REFERENCES}

[1] Pryce, J. E., Coffey, M. P., Brotherstone, S. H. (2002): Genetic relationships between calving interval and body condition score conditional on milk yield. J. of Dairy Sci, $85,1590-1595$.

[2] Perera, B. M. (2011): Reproductive cycles of buffalo. $J$. Anim. Reprod. Sci. 124 (3-4), 194-199.

[3] Afifi, E. A., Khalil, M. H., Bedeir, L. H., Zeidan, S. M. (1992): Genetic analysis of reproductive traits in Egyptian buffaloes, Egypt J. Anim. Prod., 29 (2), 139-154.

[4] Thevamanoharan, K., Vandepitte, W., Mohiuddin, G., Javed, K. (2002): Animal model heritability estimates for various production and reproduction traits of Nili-Ravi Buffaloes. International J. of Agric. and Biology, 4 (3), 357-361.

[5] Ramos, A. A., Malhado, C. H. M., Carneiro, P. L. S. (2006): Caracterizaçao fenotipica e genetica da produçao de leite e do intervalo entre partos em bubalinos da Raça Murrah, Pesquisa Agropecuaria Brasileira, 41 (8), 12611267.

[6] Jabalkandi, A., Manafiaza, G. H., Razzagzadeh, S. (2010): Effect of supplemented ration on some reproductive traits in Azeri buffaloes of Iran. Italian J. of Anim. Sci., 14, 1516.

[7] Sharma, A. K., Rodriguez, I. A., Mekonnen, G., Wilcox, C. J., Bachman, K. C., Collier, R. J. (1983a): Climatological and genetic effects on milk composition and yield, J. of Dairy Sci., 66, 119-126.

[8] Sharma, D. B., Singh, C. S. P., Mishra, H. R. (1983b): Growth rate in the she buffaloes, Indian Vet. Medicine J., 60, 1017-1018.

[9] Marai, I. F. M., Habeeb, A. A. M. (2010): Buffaloes' reproductive and productive traits as affected by heat stres, Tropical and Subtropical Agroecosystems, 12, 193-217.

[10] Aziz, M. A., Schoeman, S. J., Jordan, G. F., El-Chafie, O. M., Mahdy, A. T. (2001): Genetic and phenotypic variation of some reproductive traits in Egyptian buffalo, South African J. of Anim. Sci., 31 (3), 195-199.

[11] Prakash, A., Tripathi, V. N., Tomer, S. S. (1989): Genetic analysis of reproductive traits of Murrah buffaloes, Indian J. Dairy Sci., 42, 426-430.
[12] Schingoethe, D., Byers, F. M., Schelling, G. T. (1988): Nutrient needs during critical periods of the life cycle, The Ruminant Animal Digestive Physiology and Nutrition, 421-447.

[13] Sabra, H. A., Shalaby, S. I. A., Badawy, S. A., Hassan, S. G., Nawito, M. F. (1997): Effect of mineral mixture supplementation on postpartum period in buffaloes. $5^{\text {th }}$ World Buffalo Congress, 13-16 Oct., 1997, Caserta, Italy, Proceedings, p. 809.

[14] Borghese, A., Terzano, G. M., Barile, V. L., Annichiarico G., Parmeggani, A. (1993): Prospects of buffalo production in the Mediterranean and in the Middle East, EAAP Pubbl., 62, 370-373.

[15] İzgi, A.N., Asker, R. (1988): Effects of birth season and first calving age on lactation length and milk yield in buffaloes, Buffalo Research Inst. Publ. 19.

[16] Anonymous, (1999): Annual Report, 1988-1999. Central Institute for Research on Buffaloes, Hayrana, India.

[17] McCool, C. (1992): Buffalo and Bali cattle - Exploiting their reproductive behavior and physiology, Trop. Anim.Health Prod. 24: 165-172.

[18] Larsson, M. (2009): Water buffalo-identifying questions and possibilities from a Swedish perspective. Report from a workshop at the Royal Swedish Academy of Agriculture and Forestry 2-3 March.

[19] Fooda, T. A., Elbeltagi, A. R., Laila, R., Set El-Habaeib H., Awad, S. (2011): Evaluated of Egyptian buffaloes crossing with Italian buffaloes for reproductive traits, $J$. of American Sci., 7 (7), 209-213.

[20] Uslu, N. T. (1970): Comparative researches on various characteristics and milk yield of Afyon Region buffaloes under the village condition, Doctorate thesis, Birlik Press, Bornova, Turkey.

[21] Velea C., Bud, I., Muresan, G., David, V., Vomir, M., Cristea, C., Elisei, L. (1991): The main milk traits of Romanian buffaloes breed. Third World Buffalo Congress, Varna, Bulgaria, May 1991, Sofia, Bulgaria, Agricultural Academy, Proceedings, II, 494-499.

[22] Neog, P. K., Das, D., Goswami, R. N. (1991): Performance of Surti and Murrah buffaloes under the agroclimatic conditions of Assam, J. of the Assam Vet. Council, 1, 55-57 India.

[23] Faruque, O. (1995): Indigenous buffaloes in the coastal area of Bangladesh, Buffalo Newsletter, 4, 3-5.

[24] Metry, G. H. (1996): The main dairy animal in Egypt, Academy of Scientific and Technology, $39 \mathrm{p}$.

[25] Şekerden, Ö. (2010): Growth traits of Anatolian and Anatolian $\times$ Italian Crossbred buffalo calves and effects of genotype, sex and birth year on growth traits, $J$ of Anim. Prod. 51 (2), 34-43.

[26] Şekerden, Ö. (2011): Factors affecting somatic cell counts and their relations with milk and milk constituent yield in Anatolian and $\mathrm{F}_{1}$ Anatolian $\times$ Italian crossbred buffaloes. J of Anim. Prod. 51 (1), 9-16. 
